\title{
Potato Field Guide, Insects, Diseases and Defects
}

\author{
Eugenia Banks
}

Potato Field Guide, Insects, Diseases and Defects es una excelente contribución al conocimiento de los insectos, enfermedades causadas por hongos, bacterias, fitoplasmas, virus, viroides, nematodos, desordenes fisiológicos y otros defectos de la papa. Los temas se encuentran tratados en 19 secciones y dos apéndices. Es una obra muy bien ilustrada con 554 fotografías a color de alta calidad. Por lo tanto, es una guía muy útil para estudiantes, profesionales y agricultores dedicados a este cultivo.

\section{Potato Field Guide, Insects, Diseases and Detects \\ Eugenia Banks}

Publication 823

Ministry of Agriculture and Food

1 Stone Road West

Guelph, ON, N1G 4Y2

Canada

ISBN: 0.7794-6432-X

$170 \mathrm{pp}, 554$ fotografías a color.

Fecha de publicación: 2006

products@omaf.gov.on.ca

www. omaf.gov.on.ca

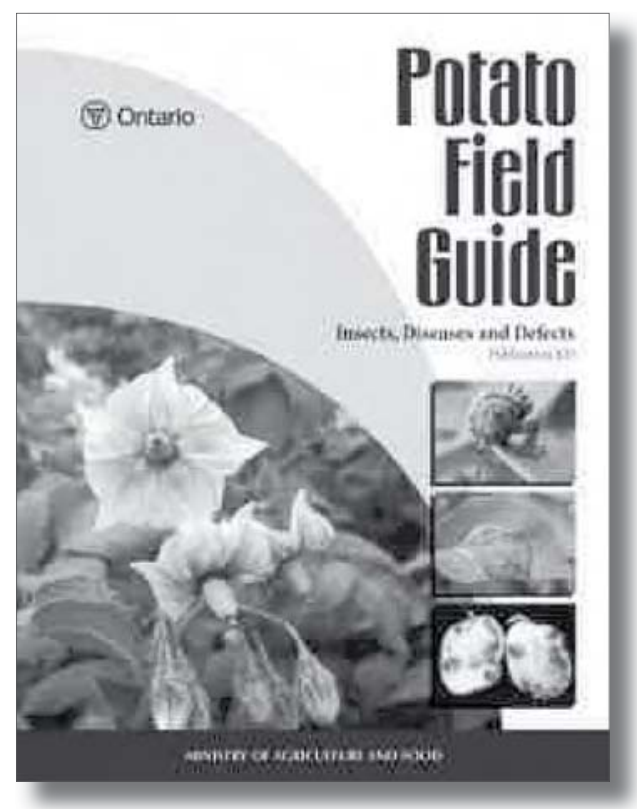

